Provided for non-commercial research and education use. Not for reproduction, distribution or commercial use.

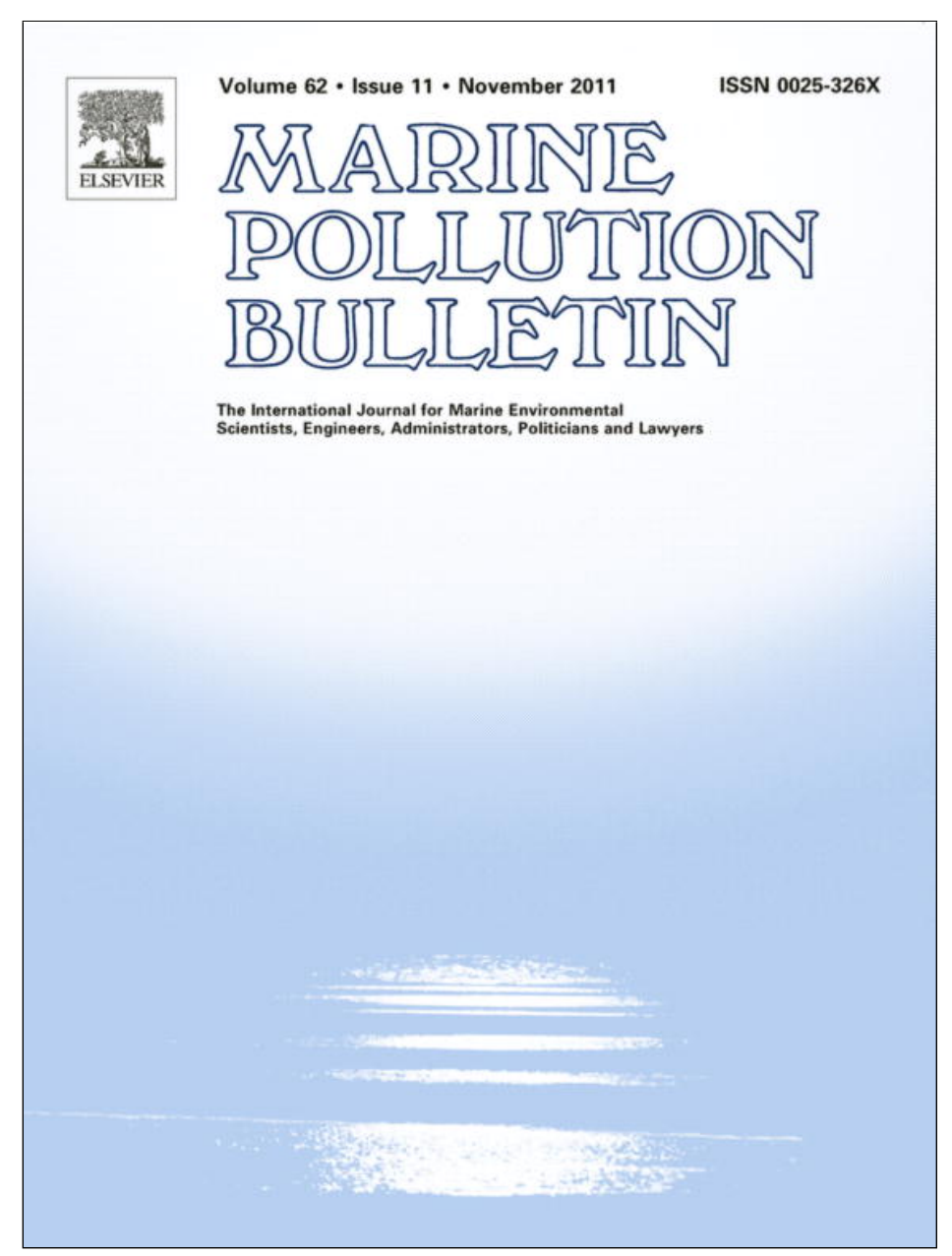

This article appeared in a journal published by Elsevier. The attached copy is furnished to the author for internal non-commercial research and education use, including for instruction at the authors institution and sharing with colleagues.

Other uses, including reproduction and distribution, or selling or licensing copies, or posting to personal, institutional or third party websites are prohibited.

In most cases authors are permitted to post their version of the article (e.g. in Word or Tex form) to their personal website or institutional repository. Authors requiring further information regarding Elsevier's archiving and manuscript policies are encouraged to visit:

http://www.elsevier.com/copyright 
Baseline

\title{
Organochlorine pesticides in sediments of Laizhou Bay and its adjacent rivers, North China
}

\author{
Guangcai Zhong ${ }^{\mathrm{a}, \mathrm{c}}$, Jianhui Tang ${ }^{\mathrm{a}, *}$, Zhen Zhao $^{\mathrm{a}}$, Xiaohui Pan ${ }^{\mathrm{a}}$, Yingjun Chen ${ }^{\mathrm{a}}$, Jun Li ${ }^{\mathrm{b}}$, Gan Zhang ${ }^{\mathrm{b}}$ \\ ${ }^{a}$ Key Laboratory of Coastal Zone Environmental Processes, Yantai Institute of Coastal Zone Research, CAS, Yantai 264003, China \\ ${ }^{\mathrm{b}}$ State Key Laboratory of Organic Geochemistry, Guangzhou Institute of Geochemistry, CAS, Guangzhou 510640, China \\ ${ }^{\mathrm{c}}$ Graduate University of Chinese Academy of Sciences, Beijing 100049, China
}

\section{A R T I C L E I N F O}

\section{Keywords:}

Bohai Sea

Laizhou Bay

Organochlorine pesticides

DDTs

Sediments

\begin{abstract}
A B S T R A C T
Organochlorine pesticides (HCHs, DDTs and HCB) have been investigated in sediments of Laizhou Bay and its adjacent rivers. The average concentrations of HCHs, DDTs and HCBs are $0.09 \mathrm{ng} / \mathrm{g} \mathrm{dw}, 0.59$ and 0.05 for marine sediments and $0.55,8.6$ and 1.1 for riverine sediments, respectively. Laizhou Bay is less contaminated by HCHs and DDTs in comparison with other coastal regions around the world, including the other two biggest bays in Bohai Sea. Fresh input of lindane and dicofol-type DDT were found in several riverine sites. Relatively strong TOC-dependence of HCB distribution in the entire studied area suggested no point source existed and/or water-sediment equilibrium achieved. No significant difference of $\alpha / \gamma-$ $\mathrm{HCH}$ ratios have been observed between marine and riverine sediments. However, o, $p^{\prime}$-DDT/p, $p^{\prime}$-DDT ratios varied largely between the two regions.
\end{abstract}

(C) 2011 Elsevier Ltd. All rights reserved.
Technical HCHs and DDTs have been widely used in China since 1950s. China is one of the most important manufactures of organochlorinated pesticides (OCPs) and accounted for $33 \%$ and $20 \%$ of the total world productions of HCHs and DDTs, respectively, during 1950s-1980s until their official bans in 1983 (Zhang et al., 2002). Despite the ban of their production and usage, fresh inputs continue to be found in the environment, which has aroused wide concerns over the world. Lindane $(\gamma-\mathrm{HCH}>90 \%)$ has been used in China since 1991 (Li et al., 2001) until its global ban under the Stockholm Convention in 2009. High concentrations of lindane has been currently observed in some of Chinese lakes, rivers and coastal regions (Fu et al., 2010; Gan et al., 2009; Gao et al., 2008; Tan et al., 2009; Zhao et al., 2009). Dicofol, which is synthesized from technical DDT and contains high levels of DDT as impurity, was found to be a "new" source of DDT in the environment in China (Qiu et al., 2004, 2005). DDT-containing antifouling paint was also discovered to be an important source of DDT in China (Lin et al., 2009; Wang et al., 2007; Zhang et al., 2007). Laizhou Bay (LB) is one of the three major bays in Bohai Sea (the other two are Liaodong Bay and Bohai Bay), making up 10\% of the total area. There are several studies on OCPs in the sediments of Liaodong Bay and Bohai Bay (Guo et al., 2009; Hu et al., 2010; Zhao et al., 2010),

\footnotetext{
* Corresponding author. Address: Key Laboratory of Coastal Zone Environmental Processes, Yantai Institute of Coastal Zone Research, Chunhui Rd 17, Laishan District, Yantai 264003, China. Tel.: +86 535 2109151; fax: +86 5352109000.

E-mail address: jhtang@yic.ac.cn (J. Tang).
}

but there is little data about the OCPs on the Laizhou Bay area. LB is situated in the north part of Shandong province. The later was one of the top five provinces in China with the highest usage of technical HCHs and DDTs (Li et al., 1999, 2001). This paper reports levels, spatial distributions and potential sources of OCPs in the surface sediments of LB and its adjacent rivers.

Fifty-six surface $(0-10 \mathrm{~cm})$ sediment samples, including 24 samples from marine sites and 32 samples from the adjacent rivers were collected in September 2009 (Fig. 1), using a stainless steel grab sampler. Locations of the marine and riverine sites together with OCP distributions are shown in Fig. 1. Details about the sampling locations and the distribution of polybrominated diphenyl ethers (PBDEs) in these sites can be found in our previous study (Pan et al., 2011).

All samples were packed in new polyethylene zipper bags and stored in a refrigerator at $-20^{\circ} \mathrm{C}$. Freeze-dried sediment samples (20 g dry weight, dw) were homogenized and Soxhlet extracted in dichloromethane (DCM) for $48 \mathrm{~h}$, with TCmX and PCB 209 (AccuStandard, Inc., USA) added as surrogates before extraction. Activated copper granules were added for desulfurization. The extract was concentrated and solvent-exchanged to hexane, then subjected to a $0.9 \mathrm{~cm}$-diameter glass column packed with $3 \mathrm{~cm}$ $3 \%$ deactivated alumina, $3 \mathrm{~cm} \mathrm{3 \%} \mathrm{deactivated} \mathrm{silica,} 3 \mathrm{~cm} \mathrm{50 \%} \mathrm{(w/}$ w) sulfuric acid-silica and anhydrous $\mathrm{Na}_{2} \mathrm{SO}_{4}$ from bottom to top. The column was eluted with $15 \mathrm{~mL} \mathrm{DCM} /$ hexane $(1: 1, \mathrm{v} / \mathrm{v})$ to yield the OCP fraction, which was then concentrated to $0.5 \mathrm{~mL}$ under a gentle nitrogen stream. This concentrated fraction was 


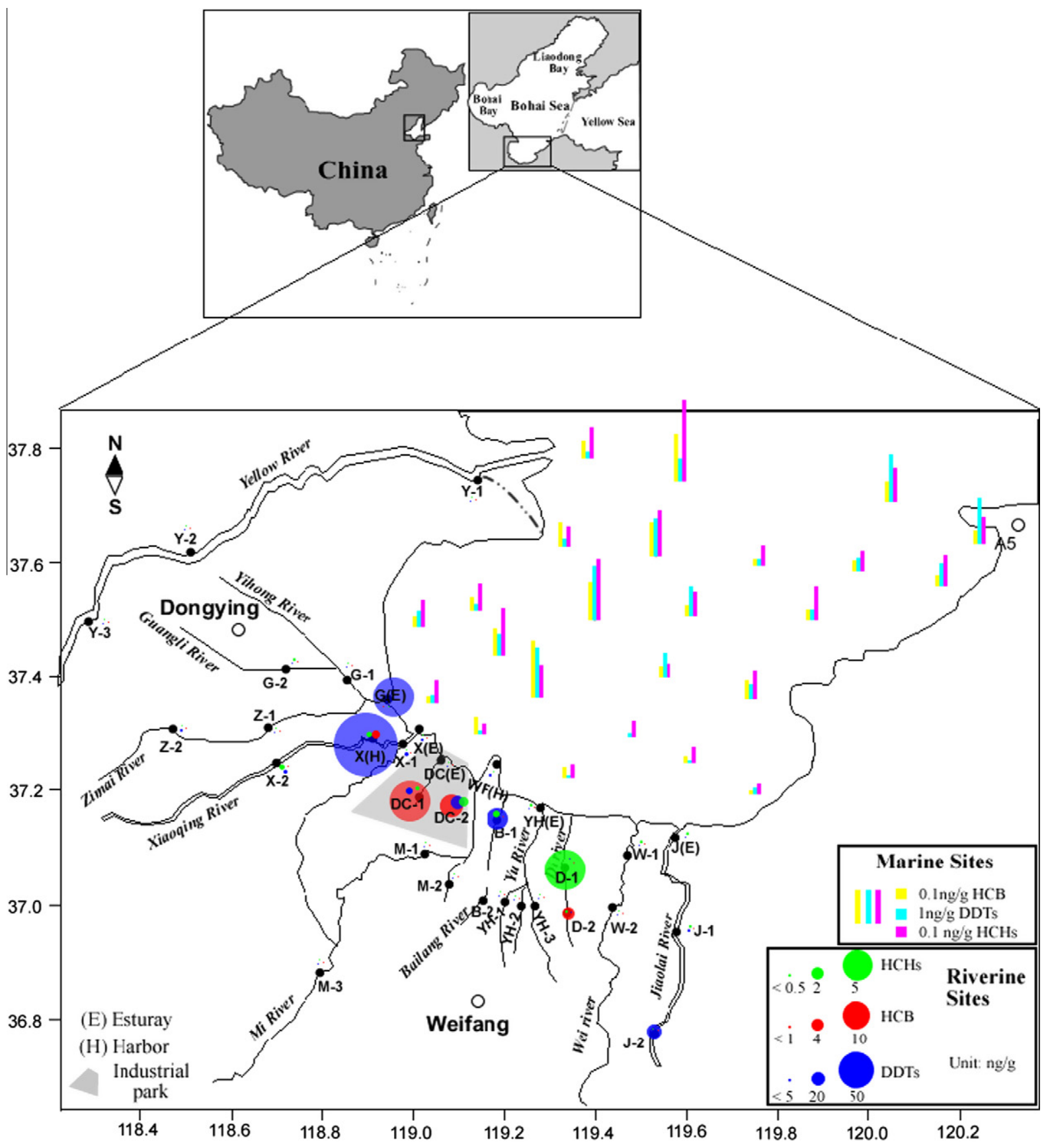

Fig. 1. Locations of sampling sites and distributions of HCHs, DDTs and HCB in riverine and marine sediments.

passed through a $2 \mathrm{~cm}$-diameter gel permeation chromatography (GPC) with $6 \mathrm{~g}$ Bio-Beads ${ }^{\circledR} \mathrm{S}-\mathrm{X} 3$ (Bio-Rad Laboratories, USA), following elution with DCM/hexane (1:1). The 15th-25th mL effluent was collected and concentrated to approximately $50 \mu \mathrm{L}$ under a gentle stream of $\mathrm{N}_{2}$. All aforementioned solvents were of analytical grade and redistilled to remove impurities prior to use. Before injection into the GC-MS, 20 ng PCB54 (AccuStandard, Inc., USA) was added as internal standard. OCPs were detected with an Agilent GC7890 equipped with a ${ }^{63} \mathrm{Ni}$ micro-electron capture detector $(\mu \mathrm{ECD})$. A CP-Sil 8 CB capillary column $(50 \mathrm{~m} \times$ $0.25 \mathrm{~mm} \times 0.25 \mu \mathrm{m}$; DB-5MS, Agilent, USA) was used, with nitrogen as carrier gas at $1.1 \mathrm{~mL} / \mathrm{min}$ under constant flow mode. Nitrogen was filtered with moisture, hydrocarbon, and oxygen traps before entering the GC-ECD system. The oven temperature began at $60^{\circ} \mathrm{C}$ for $1 \mathrm{~min}$ and increased to $180^{\circ} \mathrm{C}$ at a rate of $7^{\circ} \mathrm{C} / \mathrm{min}$, then increased to $205^{\circ} \mathrm{C}$ at a rate of $3{ }^{\circ} \mathrm{C} / \mathrm{min}$, finally increased to $290^{\circ} \mathrm{C}$ at a rate of $6{ }^{\circ} \mathrm{C} / \mathrm{min}$ (30 min hold time). Splitless injection of $1 \mu \mathrm{L}$ sample was performed with a 5 min solvent delay time. Injector temperature was $250{ }^{\circ} \mathrm{C}$. A $10 \mu \mathrm{g} / \mathrm{mL}$ OCPs standard solution containing $\alpha-\mathrm{HCH}, \beta-\mathrm{HCH}, \gamma-\mathrm{HCH}, \delta-\mathrm{HCH}$, $o, p^{\prime}$-DDT, $p, p^{\prime}$-DDT, $o, p^{\prime}$-DDD, $p, p^{\prime}$-DDD, $p, p^{\prime}$-DDE and HCB was purchased from AccuStandard, Inc. (USA) and diluted to the desired concentrations for making a six-point calibration curve. One procedural blank and one duplicate sample were conducted with every batch of 10 samples to assess potential sample contamination. The method detection limits (MDL) were 0.001$0.018 \mathrm{ng} / \mathrm{g} \mathrm{dw}$ for the detected compounds. The recovery rates for TCmX and PCB209 were $66 \pm 25 \%$ and $102 \pm 23 \%$, respectively. The reported OCP concentrations were not corrected for surrogate recoveries.

Details of OCP concentrations, including $\alpha / \gamma-\mathrm{HCH}, \beta-\mathrm{HCH} /$ $\Sigma \mathrm{HCHs}$, DDT/(DDE + DDD) and $o, p^{\prime}-\mathrm{DDT} / p, p^{\prime}-\mathrm{DDT}$ ratios at each 
Table 1

Statistics of OCPs in the riverine and marine sediments (units: $\mathrm{ng} / \mathrm{g} \mathrm{dw}$ ).

\begin{tabular}{|c|c|c|c|c|c|c|c|c|c|c|c|c|c|}
\hline & $\alpha-\mathrm{HCH}$ & $\beta-\mathrm{HCH}$ & $\gamma-\mathrm{HCH}$ & $\delta-\mathrm{HCH}$ & $\mathrm{HCB}$ & $p p-\mathrm{DDE}$ & $o p-\mathrm{DDD}$ & $p p-\mathrm{DDD}$ & op-DDT & $p p$-DDT & $\mathrm{HCHs}$ & DDTs & $\Sigma O C P s$ \\
\hline \multicolumn{14}{|c|}{ Marine sediment } \\
\hline Mean & 0.03 & 0.03 & 0.02 & 0.02 & 0.05 & 0.14 & 0.10 & 0.08 & 0.06 & 0.25 & 0.09 & 0.59 & 0.72 \\
\hline Max & 0.08 & 0.08 & 0.05 & 0.07 & 0.17 & 0.33 & 0.64 & 0.23 & 0.21 & 0.89 & 0.24 & 1.6 & 2.0 \\
\hline Min & 0.01 & BDL & $\mathrm{BDL}$ & BDL & $\mathrm{BDL}$ & 0.03 & $\mathrm{BDL}$ & 0.01 & BDL & $\mathrm{BDL}$ & 0.03 & 0.90 & 0.16 \\
\hline \multicolumn{14}{|c|}{ Riverine sediment } \\
\hline Mean & 0.09 & 0.20 & 0.26 & 0.13 & 1.1 & 2.3 & 0.73 & 1.0 & 1.6 & 4.1 & 0.55 & 8.6 & 10 \\
\hline Max & 0.30 & 1.2 & 4.9 & 0.50 & 14 & 26 & 7.9 & 15 & 15 & 45 & 6.4 & 87 & 90 \\
\hline Min & BDL & BDL & BDL & BDL & BDL & $\mathrm{BDL}$ & BDL & BDL & BDL & BDL & 0.05 & 0.10 & 0.18 \\
\hline
\end{tabular}

BDL: below detection limit.

site are shown in Table S1. Table 1 briefly summarizes the statistics of OCPs. DDTs, HCHs and HCB were detected in almost all samples. Their average concentrations are $0.59 \mathrm{ng} / \mathrm{g} \mathrm{dw}, 0.09$ and 0.05 for marine sediment and 8.6, 0.55 and 1.1 for riverine sediment, respectively. DDTs were the dominant species in most samples, which account for about $75 \%$ of total OCPs. The concentrations of OCPs in marine sediment of Laizhou Bay were lower than the other two biggest bays in the Bohai Sea (Liaodong Bay and Bohai Bay), and were at the low end of the figures in comparison with other coastal regions around the world (Table 2). The spatial distributions of the higher OCP concentrations in the center and lower in the coastal sites of Laizhou Bay were found. Significant correlations between OCPs and TOC $(r=0.8, p<0.001)$ implied that the spatial distributions of OCPs might be controlled by the TOC contents in the sediment.

The concentrations of DDTs, HCHs, and HCB in riverine sediments were lower than those in other two riverine/estuarine systems in the north and west of Bohai Sea (Table 2) (Hu et al., 2010; Zhao et al., 2010). In present study, OCP concentrations in Dihe River, a downstream site in Xiaoqing River and the small streams in the industrial park were relatively high (5.4-10 ng/ $\mathrm{g} d \mathrm{w}$ for $\Sigma$ OCPs), whereas in the largest river (Yellow River), they were relatively low (about $0.2 \mathrm{ng} / \mathrm{g} \mathrm{dw}$ for $\Sigma$ OCPs) (Fig. 1). Similar lower levels of HCHs and DDTs in the mainstream sediments of
Yellow river have been reported, which was attributed to the low content of clay and TOC of the sediment, and also the stirring up of decades-old less-contaminated sediment from river banks or the bottom of the rivers (Wang et al., 2010). Although poor correlations were found between TOC and total OCP concentrations in riverine sites, some sites with high OCP concentrations were also shown high TOC (B-1, DC -1, DC-2, D-1 and X(H)). These riverine sites with high OCPs concentrations were shown in big colored spot in Fig. 1.

Technical HCH contains $60-70 \%$ of $\alpha-\mathrm{HCH}, 5-12 \%$ of $\beta-\mathrm{HCH}, 10-$ $15 \%$ of $\gamma-\mathrm{HCH}, 6-10 \%$ of $\delta-\mathrm{HCH}$ and $3-4 \%$ of $\epsilon-\mathrm{HCH}$ (Kutz et al., $1991)$. It is generally considered that high ratios of $\alpha / \gamma(>4)$ in environments is an indication of recent use of technical HCH (Kalantzi et al., 2001), whereas a high percentage of $\gamma-\mathrm{HCH}$ indicates a contamination of Lindane. $\alpha-/ \gamma-\mathrm{HCH}$ ratios in both LB sediment and riverine sediments were lower than 3 , which indicate that fresh input of technical HCHs might not be the main source in this area. Generally, $\gamma-\mathrm{HCH}$ did not account for high percentages of total $\mathrm{HCHs}$ (average 27\%). However, $\gamma-\mathrm{HCH}$ percentages were high at several riverine sites (D-1, DC-2, M-2 and M-1) (Fig. S1), which indicates point sources of Lindane at these sites. Little difference of $\alpha-/ \gamma-\mathrm{HCH}$ ratios between marine sites and riverine sites may indicate riverine inputs are main source of $\mathrm{HCHs}$ in Laizhou Bay (Fig. 2). Higher $\beta-\mathrm{HCH} / \sum \mathrm{HCHs}$ ratios occurred at the northwestern

Table 2

Comparison of OCPs levels in sediments of Laizhou Bay with other coastal areas in the world (ng/g dw).

\begin{tabular}{|c|c|c|c|c|c|}
\hline Location & Year & $\Sigma \mathrm{HCHS}$ & ¿DDTS & $\mathrm{HCB}$ & Reference \\
\hline $\begin{array}{l}\text { Marine and Adjacent Riverine Areas of Laizhou Bay, Bohai Sea, } \\
\text { China }\end{array}$ & 2009 & $0.03-6.38(0.39)^{\mathrm{c}}$ & $\begin{array}{l}0.09- \\
86.65(4.91)^{\mathrm{a}}\end{array}$ & $\begin{array}{l}\text { n.d.- } \\
14.37(0.58)\end{array}$ & This paper \\
\hline Bohai Sea, China & 2006 & $0.16-3.17(0.83)^{\mathrm{c}}$ & $0.24-5.67(1.36)^{\mathrm{a}}$ & $0.07-0.94$ & Hu et al. (2009) \\
\hline Marine and Adjacent Riverine Areas of North Bohai Sea, China & 2008 & $\begin{array}{l}\text { n.d.- } \\
1964.97(92.51)^{c}\end{array}$ & $\begin{array}{l}<\text { LOD- } \\
86.46\left(9.23^{a}\right.\end{array}$ & - & Hu et al. (2010) \\
\hline Haihe River and Haihe Estuary Area, China & 2007 & $0.997-1620(547)^{\mathrm{c}}$ & n.d. $-155(18.5)^{\mathrm{a}}$ & n.d. $-835(173)$ & Zhao et al.(2010) \\
\hline Pearl River Estuary and the Northern South China Sea & 2002 & $0.08-1.38(0.36)^{\mathrm{c}}$ & $0.04-2.48(0.87)^{\mathrm{g}}$ & - & Chen et al.(2006) \\
\hline Yangtze Estuary, China & $\begin{array}{l}2002 \\
2004\end{array}$ & $0.5-17.5(6.0)^{c}$ & $0.9-33.1(8.2)^{\mathrm{a}}$ & - & Liu et al.(2008) \\
\hline Ha Long Bay, Hai Phong Bay, and Ba Lat Estuary, Vietnam & $\begin{array}{l}2003- \\
2004\end{array}$ & n.d. $-1.00^{c}$ & $0.31-274^{\mathrm{b}}$ & - & Hong et al.(2008) \\
\hline The whole Korean coast & $\begin{array}{l}1997- \\
2002\end{array}$ & n.d. $-5.46(0.32)^{\mathrm{c}}$ & $\begin{array}{l}0.006- \\
135(0.68)^{b}\end{array}$ & n.d. $-2.59(0.05)$ & Hong et al.(2006) \\
\hline Hugli Estuary, India & 2003 & $0.11-0.40^{c}$ & $0.18-1.93^{b}$ & $<0.05-0.98$ & Guzzella et al.(2005) \\
\hline Baltic Sea & $\begin{array}{l}2001- \\
2002\end{array}$ & $\begin{array}{l}0.007-0.4^{\mathrm{d}} 0.003- \\
0.2^{\mathrm{e}}\end{array}$ & $0.13-5.0^{\mathrm{g}}$ & $0.002-0.4$ & Pikkarainen (2007) \\
\hline Santa Monica Bay, California, USA & $\begin{array}{l}1997- \\
1999\end{array}$ & - & $1-157(38)^{\mathrm{b}}$ & - & $\begin{array}{l}\text { Venkatesan } \\
\text { et al.(2010) }\end{array}$ \\
\hline Casco Bay, Maine, USA & $\begin{array}{l}2000- \\
2001\end{array}$ & - & $0.0-455.5(2.3)^{a}$ & - & Sweet et al. (2008) \\
\hline
\end{tabular}

n.d. = not detected, $-=$ no data available, LOD $=$ limit of detection.

${ }^{\mathrm{a}} p, p^{\prime}-\mathrm{DDT}+o, p^{\prime}-\mathrm{DDT}+p, p^{\prime}-\mathrm{DDD}+p, p^{\prime}-\mathrm{DDE}$.

b $p, p^{\prime}-\mathrm{DDT}+o, p^{\prime}-\mathrm{DDT}+p, p^{\prime}-\mathrm{DDD}+o, p^{\prime}-\mathrm{DDD}+p, p^{\prime}-\mathrm{DDE}+o, p^{\prime}-\mathrm{DDE}$.

c $\alpha-\mathrm{HCH}+\beta-\mathrm{HCH}+\delta-\mathrm{HCH}+\gamma-\mathrm{HCH}$.

d $\alpha-\mathrm{HCH}$.

e $\gamma-\mathrm{HCH}$.

${ }^{g} p, p^{\prime}-\mathrm{DDT}+p, p^{\prime}-\mathrm{DDD}+p, p^{\prime}-\mathrm{DDE}$. 


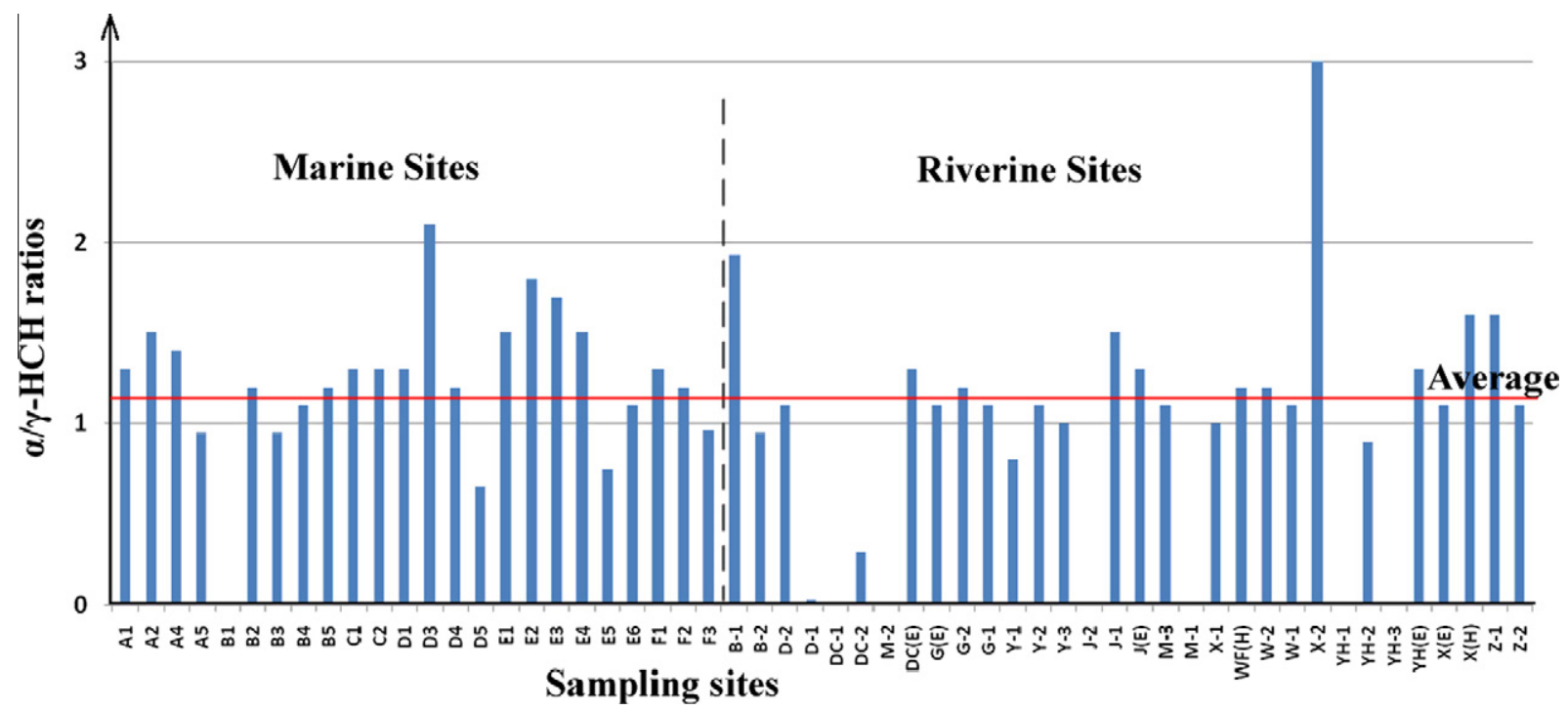

Fig. 2. Comparisons of $\alpha / \gamma-\mathrm{HCH}$ ratios between marine and riverine sites.

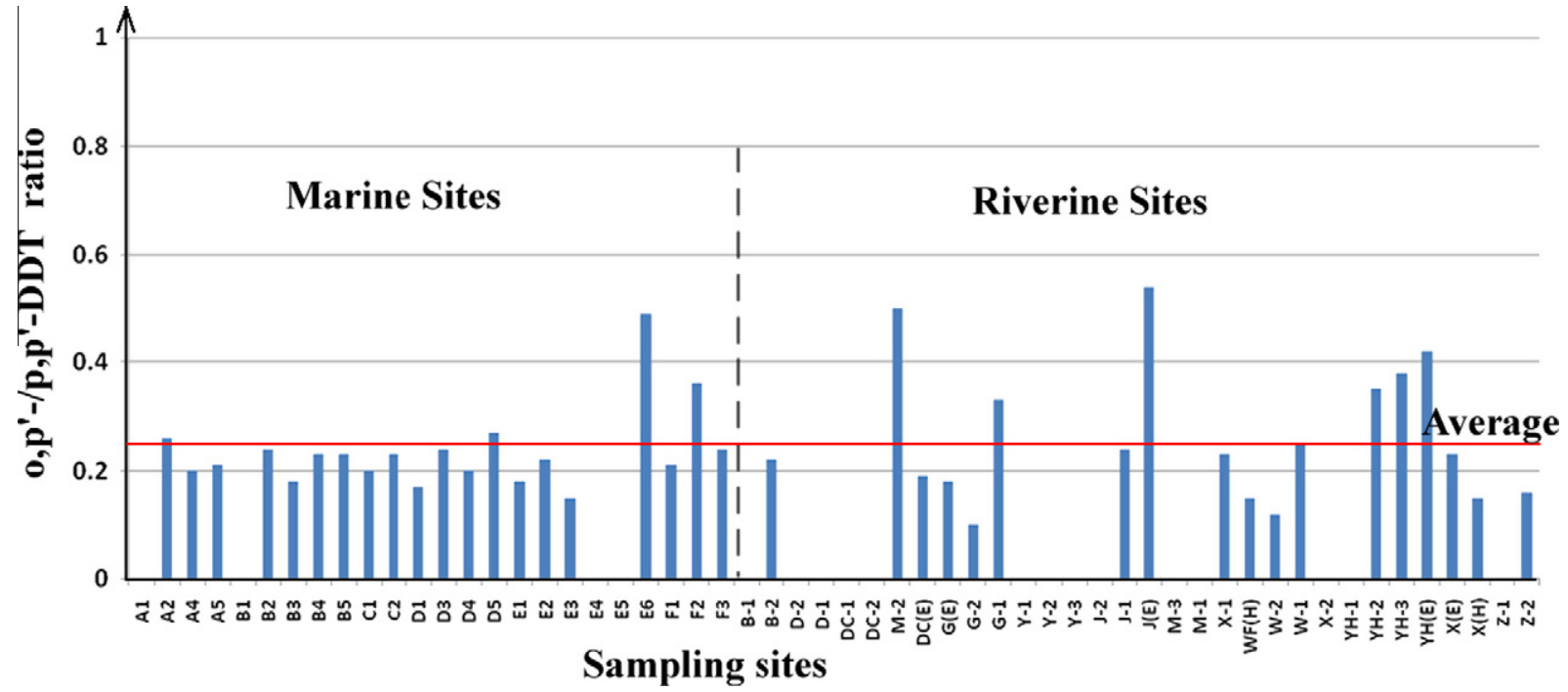

Fig. 3. Comparisons of $o, p^{\prime}$-DDT/p, $p^{\prime}$-DDT ratios between marine and riverine sites. $\left(o, p^{\prime}\right.$-DDT/p,p'-DDT ratios of B-1, DC-1, DC- 2 were not shown, as the extremely high values).

part of Laizhou Bay, where high $\Sigma$ HCHs existed. The physical and chemical properties of $\mathrm{HCH}$ isomers varied with each other. $\alpha$ $\mathrm{HCH}$ and $\gamma-\mathrm{HCH}$ dominant in air and seawater due to their higher volatility and lower Henry's law constant or partition coefficient (Kumar et al., 2009; Li et al., 1999). $\beta-\mathrm{HCH}$ has a lower volatility and higher $\log K_{\text {ow }}$ than other isomers and as a result is frequently detected in sediments (Li et al., 1999). Moreover, $\alpha$ - and $\gamma$-HCH can transform to $\beta-\mathrm{HCH}$ in aged environmental samples (Walker et al., 1999). As a result, higher $\Sigma \mathrm{HCHs}$ and greater proportions of $\beta-\mathrm{HCH}$ in the northwestern Laizhou Bay indicate that accumulation of historical usage and possible long-term sedimentation of technical $\mathrm{HCHs}$ in this region. $\mathrm{HCHs}$ concentrations at marine sites showed good correlation with $\mathrm{HCB}$ concentrations $(r=0.73, p<0.001)$, which may suggest similar movement or/and common sources of these compounds in marine sediment. DDTs and $\mathrm{HCHs}$ in riverine sediments showed poor $(r=0.24, p>0.1)$ and moderate $(r=0.59$, $p<0.01$ ) correlation with TOC, respectively. However, concentrations of HCB in both marine and riverine sediments correlated significantly with TOC $(r=0.80, p<0.001$ and $r=0.74, p<0.001$, respectively). Relatively strong TOC-dependence of HCB distribution in the entire studied area suggested no point source and/or water-sediment equilibrium.

DDT is likely to be dehydrochlorinated to DDE as well as DDD under aerobic conditions and anaerobic conditions, respectively. Thus a high ratio of DDT/(DDE + DDD) can be used as an indicator of fresh input of DDT (Hitch and Day, 1992). In this study, the value of DDT/(DDE + DDD) in marine sediments ranged from 0.3 to 3 with an average of 1 , indicating no significant fresh pollution of DDT. For riverine sediments, the average value of DDT/ (DDE + DDD) ratios was 2 (ranged from 0 to 18), excluding three sites (DC(E), J-2, Y-1) with DDT/(DDE + DDD) ratios $>10$. This reveals that there are fresh inputs of DDT in these three sites. Although the Chinese government banned the use of technical DDT as pesticide since 1983, new DDT sources have still entered in the environment from the application of Dicofol, as studies revealed recently (Qiu et al., 2004; Qiu et al., 2005). To distinguish technical DDT and dicofol type DDT pollution, the concentration ratio of $o, p^{\prime}$-DDT $/ p, p^{\prime}$-DDT is calculated (Fig. 3). Technical DDTs 
contain $15-21 \%$ of $o, p^{\prime}$-DDT and $65-85 \%$ of $p, p^{\prime}$-DDT (Metcalf, 1955). A survey of formulated dicofol in the Chinese market gave an $0, p^{\prime}$-DDT $/ p, p^{\prime}$-DDT ratio of 7 (Qiu et al., 2005). So, high $o, p^{\prime}-$ $\mathrm{DDT} / p, p^{\prime}$-DDT ratios can service as an indicator of dicofol-type DDT sources. $o, p^{\prime}$-DDT $/ p, p^{\prime}$-DDT ratios in our study are $<1$, excluding three riverine samples (1.9 for B-1, 37 for DC-1, and 7.9 for DC$2)$. This suggested widespread technical DDT pollution, whereas the high $o, p^{\prime}$-DDT $/ p, p^{\prime}$-DDT ratios at DC- 1 and DC-2 were possibly attributed to a production of dicofol in the industrial park which is mainly used in salt industry. This result is consistent with the conclusion that there was heavier usage of technical DDT in central and eastern China, in contrast with more widespread dicofol DDT contamination in southern and eastern China. o, $p^{\prime}$-DDT $/ p, p^{\prime}$-DDT ratios in marine sediments are relatively uniform, whereas $o, p^{\prime}$ $\mathrm{DDT} / p, p^{\prime}$-DDT ratios in riverine sediments varied largely, which suggested riverine input was not the only source of DDTs in Laizhou Bay.

\section{Acknowledgements}

The study was funded by the Chinese Academy of Sciences Initiative Projects (KZCX2-YW-Q07-04 and KZCX2-EN-QN210), the CAS/SAFEA International Partnership Program for Creative Research Teams Project and Shandong Province Project (2007GG2QT06018).

\section{Appendix A. Supplementary data}

Supplementary data associated with this article can be found, in the online version, at doi:10.1016/j.marpolbul.2011.08.018.

\section{References}

Chen, S.J., Luo, X.J., Mai, B.X., Sheng, G.Y., Fu, J.M., Zeng, E.Y., 2006. Distribution and mass inventories of polycyclic aromatic hydrocarbons and organochlorine pesticides in sediments of the Pearl River Estuary and the northern South China Sea. Environ. Sci. Technol. 40, 709-714.

Fu, L.Y., Luo, J., Hu, J.W., Wu, Q., Huang, X.F., Tian, L.F., 2010. Estimation of organochlorine pesticides (DDT and $\mathrm{HCH}$ ) in surface sediments from Baihua Lake. In:Selected Proceedings of the Fifth International Conference on Waste Management and Technology (Icwmt 5),pp. 534-538.

Gan, J.L., Jia, X.P., Jia, T., Lin, Q., Cai, W.G., 2009. Distribution and change of DDT and HCH levels in oysters (Crassostrea rivularis) from coast of Guangdong, China between 2003 and 2007. J. Environ. Sci. Heal. B. 44, 817-822.

Gao, J.J., Liu, L.H., Liu, X.R., Lu, J., Zhou, H.D., Huang, S.B., Wang, Z.J., Spear, P.A., 2008. Occurrence and distribution of organochlorine pesticides-lindane, $p, p^{\prime}$-DDT, and heptachlor epoxide - in surface water of China. Environ. Int. 34, 1097-1103.

Guo, Z.G., Hu, L.M., Zhang, G., Zheng, B.H., Qin, Y.W., Lin, T., 2009. Occurrence and distribution of organochlorine pesticides (OCPs) in surface sediments of the Bohai Sea, China. Chemosphere 77, 663-672.

Guzzella, L., Roscioli, C., Vigano, L., Saha, M., Sarkar, S.K., Bhattacharya, A., 2005. Evaluation of the concentration of $\mathrm{HCH}, \mathrm{DDT}, \mathrm{HCB}, \mathrm{PCB}$ and $\mathrm{PAH}$ in the sediments along the lower stretch of Hugli estuary, West Bengal, northeast India. Environ. Int. 31, 523-534.

Hitch, R.K., Day, H.R., 1992. Unusual persistence of Ddt in some Western USA soils. Bull. Environ. Contam. Toxicol. 48, 259-264.

Hong, S.H., Yim, U.H., Shim, W.J., Li, D.H., Oh, J.R., 2006. Nationwide monitoring of polychlorinated biphenyls and organochlorine pesticides in sediments from coastal environment of Korea. Chemosphere 64, 1479-1488.

Hong, S.H., Yim, U.H., Shim, W.J., Oh, J.R., Viet, P.H., Park, P.S., 2008. Persistent organochlorine residues in estuarine and marine sediments from Ha Long Bay, Hai Phong Bay, and Ba Lat Estuary, Vietnam. Chemosphere 72, 1193-1202.
Hu, L.M., Zhang, G., Zheng, M.H., Qin, Y.W., Lin, T., Guo, Z.G., 2009. Occurrence and distribution of organochlorine pesticides (OCPs) in surface sediments of the Bohai Sea, China. Chemosphere 77, 663-672.

Hu, W.Y., Wang, T.Y., Khim, J.S., Luo, W., Jiao, W.T., Lu, Y.L., Naile, J.E., Chen, C.L., Zhang, X.A., Giesy, J.P., 2010. HCH and DDT in sediments from marine and adjacent Riverine Areas of North Bohai Sea, China. Arch. Environ. Contam. Toxicol. 59, 71-79.

Kalantzi, O.I., Alcock, R.E., Johnston, P.A., Santillo, D., Stringer, R.L., Thomas, G.O., Jones, K.C., 2001. The global distribution of PCBs and organochlorine pesticides in butter. Environ. Sci. Technol. 35, 1013-1018.

Kumar, M.S., Bhatt, P., Chakrabarti, T., 2009. Fate and degradation of POPhexachlorocyclohexane. Crit. Rev. Environ. Sci. Technol. 39, 655-695.

Kutz, F.W., Wood, P.H., Bottimore, D.P., 1991. Organochlorine pesticides and polychlorinated-biphenyls in human adipose-tissue. Rev. Environ. Contam. Tox. 120, 1-82.

Li, Y.F., Cai, D.J., Shan, Z.J., Zhu, Z.L., 2001. Gridded usage inventories of technical hexachlorocyclohexane and lindane for china with $1 / 6$ degrees latitude by $1 / 4$ degrees longitude resolution. Arch. Environ. Contam. Toxicol. 41, 261-266.

Li, Y.F., Cai, D.J., Singh, A., 1999. Historical DDT use trends in China and usage data gridding with $1 / 4$ by $1 / 6$ longitude/latitude resolution. Adv. Environ. Res. 2, 497-506.

Lin, T., Hu, Z.H., Zhang, G., Li, X.D., Xu, W.H., Tang, J.H., Li, J., 2009. Levels and mass burden of DDTs in sediments from fishing harbors: the importance of DDTcontaining antifouling paint to the coastal environment of China. Environ. Sci. Technol. 43, 8033-8038.

Liu, M., Cheng, S.B., Ou, D.N., Yang, Y., Liu, H.L., Hou, L.J., Gao, L., Xu, S.Y., 2008. Organochlorine pesticides in surface sediments and suspended particulate matters from the Yangtze estuary, China. Environ. Pollut. 156, 168-173.

Metcalf, R.L., 1955. Organic Insecticides Their Chemistry and Mode of Action. Interscience, New York.

Pikkarainen, A.L., 2007. Polychlorinated biphenyls and organochlorine pesticides in Baltic Sea sediments and bivalves. Chemosphere 68, 17-24.

Qiu, X.H., Zhu, T., Jing, L., Pan, H.S., Li, Q.L., Miao, G.F., Gong, J.C., 2004. Organochlorine pesticides in the air around the Taihu Lake, China. Environ. Sci. Technol. 38, 1368-1374.

Qiu, X.H., Zhu, T., Yao, B., Hu, J.X., Hu, S.W., 2005. Contribution of dicofol to the current DDT pollution in China. Environ. Sci. Technol. 39, 4385-4390.

Pan, X.H., Tang, J.H., Li, J., Zhong, G.C., Chen, Y.J., Zhang, G., 2011. Polybrominated diphenyl ethers (PBDEs) in the riverine and marine sediments of the Laizhou Bay area, North China. J. Environ. Monitor. 13, 886-893.

Sweet, S.T., Wade, T.L., Klein, A.G., 2008. Assessment of sediment contamination in Casco Bay, Maine, USA. Environ. Pollut. 152, 505-521.

Tan, L., He, M.C., Men, B., Lin, C.Y., 2009. Distribution and sources of organochlorine pesticides in water and sediments from Daliao River estuary of Liaodong Bay, Bohai Sea (China). Estuar. Coast. Shelf S. 84, 119-127.

Venkatesan, M.I., Merino, O., Baek, J., Northrup, T., Sheng, Y., Shisko, J., 2010. Trace organic contaminants and their sources in surface sediments of Santa Monica Bay, California, USA. Mar. Environ. Res. 69, 350-362.

Walker, K., Vallero, D.A., Lewis, R.G., 1999. Factors influencing the distribution of lindane and other hexachlorocyclohexanes in the environment. Environ. Sci. Technol. 33, 4373-4378.

Wang, J., Guo, L.L., Li, J., Zhang, G., Lee, C.S.L., Li, X.D., Jones, K.C., Xiang, Y.R., Zhong, L.J., 2007. Passive air sampling of DDT, chlordane and HCB in the Pearl River Delta, South China: implications to regional sources. J. Environ. Monitor. 9, 582Delta,

Wang, G.L., Ma, L.M., Sun, J.H., Zhang, G., 2010. Occurrence and distribution of organochlorine pesticides (DDT and $\mathrm{HCH}$ ) in sediments from the middle and lower reaches of the Yellow River, China. Environ. Monitor. Asses. 168, 511-

521.
Zhang, G., Parker, A., House, A., Mai, B.X., Li, X.D., Kang, Y.H., Wang, Z.S., 2002. Sedimentary records of DDT and HCH in the Pearl River Delta, South China. Environ. Sci. Technol. 36, 3671-3677.

Zhang, G., Li, J., Cheng, H., Li, X., Xu, W., Jones, K.C., 2007. Distribution of organochlorine pesticides in the northern South China Sea: implications for land outflow and air-sea exchange. Environ. Sci. Technol. 41, 3884-3890.

Zhao, Z.H., Zhang, L., Wu, J.L., Fan, C.X., 2009. Distribution and bioaccumulation of organochlorine pesticides in surface sediments and benthic organisms from Taihu Lake, China. Chemosphere 77, 1191-1198.

Zhao, L., Hou, H., Zhou, Y.Y., Xue, N.D., Li, H.Y., Li, F.S., 2010. Distribution and ecological risk of polychlorinated biphenyls and organochlorine pesticides in surficial sediments from Haihe River and Haihe Estuary Area, China. Chemosphere 78, 1285-1293. 